\title{
Peroxynitrite Generation and Increased Heterotrophic Capacity Are Linked to the Disruption of the Coral-Dinoflagellate Symbiosis in a Scleractinian and Hydrocoral Species
}

\author{
Laura Fernandes de Barros Marangoni 1,2,3,*® , Miguel Mies ${ }^{2,4}$, Arthur Z. Güth ${ }^{4} \oplus$, \\ Thomás N. S. Banha ${ }^{4} \mathbb{D}^{\circ}$, Alex Inague ${ }^{5}{ }^{(\mathbb{D}}$, Juliana da Silva Fonseca ${ }^{6}$, Camila Dalmolin ${ }^{6}$, \\ Samuel Coelho Faria ${ }^{7,8}(\mathbb{D})$, Christine Ferrier-Pagès ${ }^{3}(\mathbb{D})$ and Adalto Bianchini ${ }^{1,2,6}{ }^{(D)}$ \\ 1 Pós-Graduação em Oceanografia Biológica, Oceanographic Institute, Federal University of Rio Grande, \\ Av. Itália, Km 8, Rio Grande, RS 96203-900, Brazil; adaltobianchini@furg.br \\ 2 Coral Vivo Institute, Rua dos Coqueiros, Parque Yaya, Santa Cruz Cabrália, BA 45.807-000, Brazil; \\ miguel.mies@usp.br \\ 3 Centre Scientifique de Monaco, Marine Department, 8 Quai Antoine 1er, MC-98000, Monaco; \\ ferrier@centrescientifique.mc \\ 4 Oceanographic Institute, University of São Paulo. Praça do Oceanográfico, 191-05508-120 São Paulo, SP, \\ Brazil; azguth@gmail.com (A.Z.G.); sotobanha@gmail.com (T.N.S.B.) \\ 5 Chemistry Institute, University of São Paulo. Av Prof Lineu Prestes, 748-05508-000 São Paulo, SP, Brazil; \\ inague.alex@gmail.com \\ 6 Pós-Graduação em Ciências Fisiológicas, Biological Science Institute, Federal University of Rio Grande, \\ Av. Itália, Km 8, Rio Grande, RS 96203-900, Brazil; julianafonseca94@hotmail.com (J.S.F.); \\ camidal@gmail.com (C.D.) \\ 7 Institute of Biosciences, University of São Paulo. São Paulo, SP 05508-090, Brazil; scoelhofaria@gmail.com \\ 8 Bermuda Institute of Ocean Sciences, St. George's GE01, Bermuda \\ * Correspondence: laurafbmarangoni@gmail.com or lmarangoni@centrescientifique.mc
}

Received: 11 July 2019; Accepted: 16 September 2019; Published: 9 October 2019

\begin{abstract}
Ocean warming is one of the greatest global threats to coral reef ecosystems; it leads to the disruption of the coral-dinoflagellate symbiosis (bleaching) and to nutrient starvation, because corals mostly rely on autotrophy (i.e., the supply of photosynthates from the dinoflagellate symbionts) for their energy requirements. Although coral bleaching has been well studied, the early warning signs of bleaching, as well as the capacity of corals to shift from autotrophy to heterotrophy, are still under investigation. In this study, we evaluated the bleaching occurrence of the scleractinian coral Mussismillia harttii and the hydrocoral Millepora alcicornis during a natural thermal stress event, under the 2015-2016 El Niño influence in three reef sites of the South Atlantic. We focused on the link between peroxynitrite $\left(\mathrm{ONOO}^{-}\right)$generation and coral bleaching, as $\mathrm{ONOO}^{-}$has been very poorly investigated in corals and never during a natural bleaching event. We also investigated the natural trophic plasticity of the two corals through the use of new lipid biomarkers. The results obtained first demonstrate that $\mathrm{ONOO}^{-}$is linked to the onset and intensity of bleaching in both scleractinian corals and hydrocorals. Indeed, $\mathrm{ONOO}^{-}$concentrations were correlated with bleaching intensity, with the highest levels preceding the highest bleaching intensity. The time lag between bleaching and $\mathrm{ONOO}^{-}$peak was, however, species-specific. In addition, we observed that elevated temperatures forced heterotrophy in scleractinian corals, as $M u$. harttii presented high heterotrophic activity 15 to 30 days prior bleaching occurrence. On the contrary, a lower heterotrophic activity was monitored for the hydrocoral Mi. alicornis, which also experienced higher bleaching levels compared to $M u$. hartii. Overall, we showed that the levels of $\mathrm{ONOO}^{-}$in coral tissue, combined to the heterotrophic capacity, are two good proxies explaining the intensity of coral bleaching.
\end{abstract}


Keywords: coral reefs; heterotrophy; hydrocorals; oxidative stress; reactive nitrogen species

\section{Introduction}

Ocean warming is one of the greatest global threats to coral reef ecosystems [1]. Such a threat can be even more intense during pulse heat stress events, such as those occurring during the El Niño Southern Oscillation (ENSO) [2]. The 2015-2016 ENSO, which caused unprecedented elevation in seawater temperatures, triggered the third global-scale event of mass coral bleaching [2,3], affecting $75 \%$ of the world's reefs [1]. Coral bleaching is a complex physiological process characterized by the disruption of the symbiosis between the coral host and its endosymbiotic Symbiodiniaceae dinoflagellates $[4,5]$. Since dinoflagellates provide most of the nutritional needs of the symbiotic association through their autotrophic acquisition of energy [6,7], their loss can severely impact the corals' energetic state, and on the long term, can lead to coral death. Many studies have thus focused on understanding the factors and processes that trigger coral bleaching.

At the physiological level, it has been demonstrated that coral species able to shift from an autotrophic to a heterotrophic mode of nutrition (i.e., plankton predation by the coral host) can be more resistant or resilient to bleaching [8,9]. Although the natural heterotrophic capacity of corals is difficult to assess, a recent study has developed fatty acid markers, which can quantitatively determine the predominance of autotrophy and heterotrophy in corals [10]. Specifically, stearidonic acid (SDA, 18:4 $\mathrm{\omega} 3$ ) and docosapentaenoic acid (DPA, 22:5 $\mathrm{\omega 3}$ ) are fatty acids that have been validated as trophic markers for autotrophic feeding in corals, while cis-gondoic acid (CGA, 20:1 $\omega 9)$ has been validated as a marker for heterotrophic feeding [10]. Temporal variations in these fatty acids are used to calculate the Predominant Trophic Mode Index (PTMI), which determines the predominant feeding mode between autotrophy and heterotrophy [10]. Such an index has, however, never been used to assess the trophic mode of corals experiencing a global thermal stress event.

At the cellular level, over two decades of research have implicated oxidants, including reactive oxygen and nitrogen species (ROS and RNS, respectively), as pivotal factors responsible for coral bleaching [11-19]. More specifically, under thermal stress conditions, increasing amounts of superoxide anion $\left(\mathrm{O}_{2}^{-}\right)$can be produced in the inner mitochondrial membrane and in the chloroplasts [20]. Also, symbiotic cnidarians under thermal stress can present increased nitric oxide (NO) concentrations, a RNS implicated in numerous cell signaling and pathophysiological processes in eukaryotic cells [14]. In presence of $\mathrm{O}_{2}{ }^{-}, \mathrm{NO}$ can be converted into peroxynitrite $\left(\mathrm{ONOO}^{-}\right)$, a very reactive RNS known to cause irreversible damages to biomolecules [21]. Although the implication of NO in coral bleaching has been previously studied in laboratory experiments $[14,15,18,22,23]$, its role in the production of $\mathrm{ONOO}^{-}$, during natural bleaching events remains unclear [16].

In this field work, we specifically studied the bleaching occurrence of two coral species, the scleractinian Mussismillia harttii and the hydrocoral Millepora alcicornis, during a natural bleaching event occurring during the 2015-2016 El Niño. To further our knowledge on the role of heterotrophy and $\mathrm{ONOO}^{-}$generation in bleaching susceptibility, we followed these two parameters, together with seawater temperatures, in three different reef sites located in the South Atlantic. This is the first attempt to link $\mathrm{ONOO}^{-}$production and in situ coral bleaching, as well as to assess in situ heterotrophy of a scleractinian and hydrocoral using the PTMI index.

\section{Materials and Methods}

\subsection{Reef Sites}

Three reef sites located at the conservation area of the Municipal Natural Park of Recife de Fora (Porto Seguro, Bahia, Northeastern Brazil) were surveyed: (1) Taquaruçu ( $16^{\circ} 24^{\prime} 25.3^{\prime \prime} \mathrm{S}, 38^{\circ} 58^{\prime} 41.0^{\prime \prime} \mathrm{W}$ );

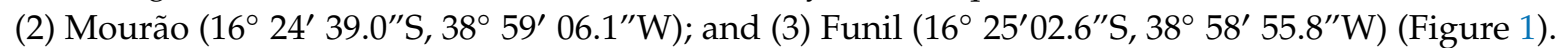


Repeated surveys of a particular location are typically less spatially comprehensive than stratified random surveys, however, are considered a useful sampling design to provide information on stress and degradation of coral reefs [24]. Therefore, the repeated surveys in representative sections of the Recife de Fora Marine Protected Area was considered the best approach, considering the temporal scale of our study and the aim to assess physiological responses in corals. The sites were selected according to the National Oceanic and Atmospheric Administration (NOAA) predictions for coral bleaching occurrence (https://coralreefwatch.noaa.gov/satellite/analyses_guidance/global_coral_bleaching_2014_ 17_status.php). In addition, they are included in the Brazilian Reef Check monitoring program (www.reefcheck.org, www.recifescosteiros.org.br), and are part of a recent Brazilian Conservation Plan for Endangered Species of Reef Environments (PAN Corais, ICMBio, 2016). Mussismilia harttii and Mi. alcicornis are the most abundant corals in these sites (unpublished data, E. N. Calderon) and were chosen in this study.

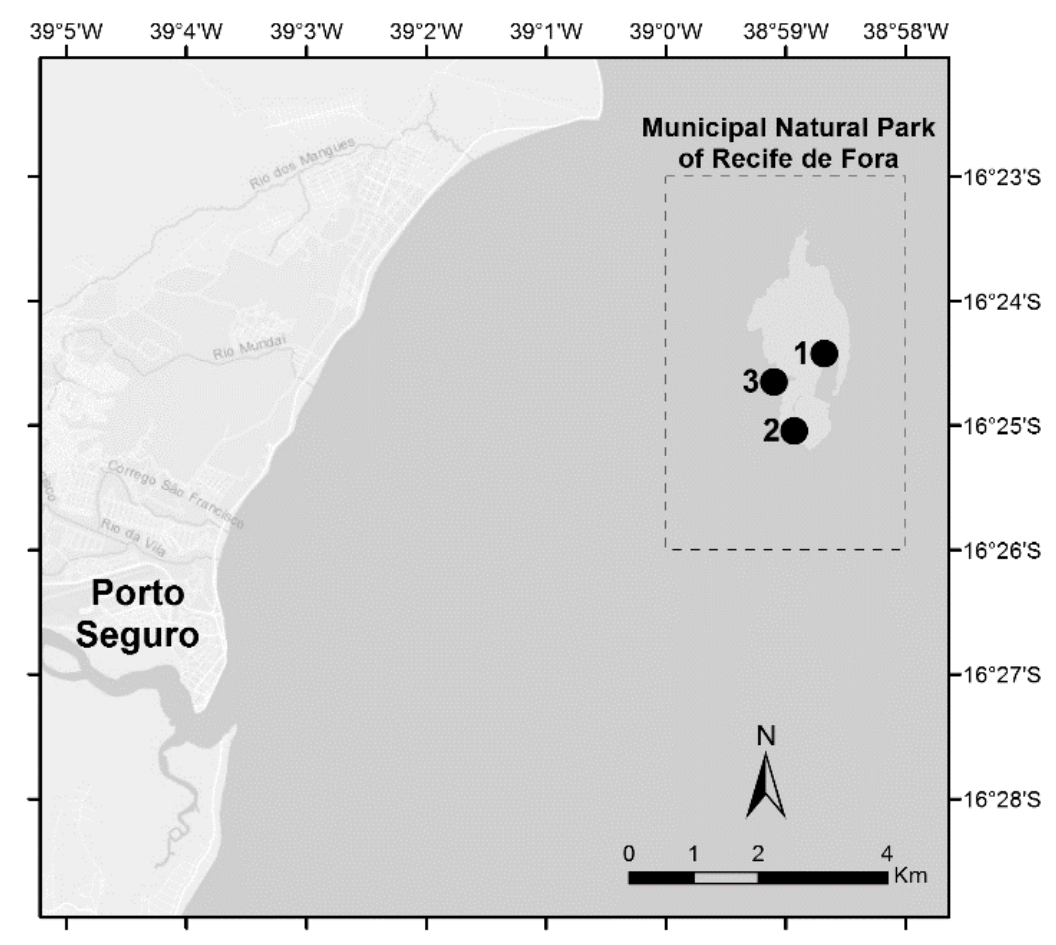

Figure 1. Study area of the Recife de Fora Marine Protected Area in the Southwestern Atlantic, Brazil. Reef sites: (1) Taquaruçu, (2) Mourão, (3) Funil. (Adapted from Marangoni et al. 2019).

\subsection{Thermal Stress Assessment}

Local temperature conditions were assessed using in situ temperature data loggers (HOBO Pendant model UA-002-64) and historical data records obtained from NOAA's $5 \mathrm{~km}$ virtual station, Recife de Fora, Brazil. In situ water temperature was continuously recorded every 15 min throughout the monitoring period (15, December, 2015 to 15, June, 2016). Data processing followed methods developed by NOAA Coral Reef Watch (CRW) program and ReefTemp monitoring system [25]. Data obtained from the NOAA virtual station for March 2013 to December 2015 were combined with in situ temperature data from December 2015 onwards, to calculate: (i) the onset of potential coral bleaching, which was defined to begin at degree heating weeks (DHW) values of $4{ }^{\circ} \mathrm{C}$-weeks or greater; and (ii) sea surface temperature anomaly (SSTA), calculated as the positive deviations of daily average temperatures from the long-term (4 years) average temperature observed for each month. DHW are the accumulation of temperature anomalies exceeding the maximum of the monthly mean SST for a given region over the last 12-week period [26-28]. To calculate DHW, only anomalies $\geq 1{ }^{\circ} \mathrm{C}$ were considered [29]. 


\subsection{Biological Survey}

Colonies of the scleractinian coral $M u$. harttii and the hydrocoral Mi. alcicornis were surveyed by SCUBA diving for changes in colony coloration every 15 days, from December 15th, 2015 to June 15th, 2016. One transect of $20 \times 2 \mathrm{~m}$, at a depth of $2 \mathrm{~m}$ (low tide), was haphazardly fixed each time and performed in each of the three sites. Colonies were photographed next to a PVC Coral Health Chart [30] along the fixed transects. The number of $M u$. harttii and Mi. alcicornis colonies photographed in each of the transects varied from 8-34 and 18-33, respectively. Bleaching occurrence was evaluated following the modified coral watch protocol (www.reefquest.org). Colonies that were inside (at least in part) of each transect $(20 \times 2 \mathrm{~m})$ were recorded, and coral colonies were considered "bleached" if at least $50 \%$ of its surface area was bleached. In addition, biological samples from both species were collected every 15 days for each site alongside all transects within an area of $0.04 \mathrm{~km}^{2}$. For each transect, 4 colonies per species were sampled, with one polyp for $M u$. harttii and an apical piece of approximately $3 \mathrm{~cm}$ for Mi. alcicornis. Completely bleached colonies were avoided since they tend to loose tissue biomass (e.g., protein total content), which could affect biochemical assays conducted in the present study. Fragments were cut and immediately frozen in liquid nitrogen for subsequent analyses. Collections were performed under the permission of the Brazilian Environmental Agency (SISBIO).

\subsection{Physiological Measurements}

\subsubsection{Fatty Acids Extraction and Analysis}

Mussimilia harttii and Mi. alcicornis fragments were weighed and lipid extraction was performed according to Mies et al. [31]. Coral tissues were crushed [32] and incubated with $50 \mu \mathrm{L}$ of tridecanoic acid (C13:0, $\left.1.0 \mathrm{mg} \mathrm{mL}^{-1}\right), 1.85 \mathrm{~mL}$ of methanol, and $100 \mu \mathrm{L}$ of acetyl chloride for $1 \mathrm{~h}$ at $100{ }^{\circ} \mathrm{C}$. Hexane was added, the sample vortexed, and the upper organic phase transferred to a new vial. Evaporation was performed under a $\mathrm{N}$ flow $_{2}$ until drying and the content was then resuspended in $100 \mu \mathrm{L}$ of hexane. Fatty acid methyl esters (FAME) were analyzed on a Trace 1310 gas chromatograph (Thermo Scientific) equipped with a flame ionization detector. FAME were separated with a DB-FFAP column of $15 \mathrm{~m} \times$ $0.1 \mathrm{~mm}$ ID $\times 0.1 \mu \mathrm{m}$ film thickness (J \& W Scientific, Agilent Technologies). The program started at 150 ${ }^{\circ} \mathrm{C}$ for $15 \mathrm{~s}$, increasing $35^{\circ} \mathrm{C}$ per minute up to $200^{\circ} \mathrm{C}$, and $8{ }^{\circ} \mathrm{C}$ per minute up to $250{ }^{\circ} \mathrm{C}$ and maintained for $4 \mathrm{~min}$. Next, $1 \mu \mathrm{L}$ of the sample was injected and carried by a mixture of hydrogen and nitrogen.

The identification of stearidonic acid (SDA), docosapentaenoic acid (DPA), and cis-gondoic acid (CGA) was done by direct comparison of their retention times with 47033 PUFA N ${ }^{\circ} 1$ Marine Source (Sigma-Aldrich) standard mix. For each chromatogram, peaks were integrated and normalized by the internal standard. After the extraction, the skeleton fragments were washed with $2 \% \mathrm{NaClO}$ for $2 \mathrm{~min}$ and dried at $63{ }^{\circ} \mathrm{C}$ for $30 \mathrm{~h}$ to remove organic tissue. The fragments were reweighed and both soft tissue and skeleton weight were determined.

\subsubsection{Predominant Trophic Mode Index}

To determine which feeding mode prevailed, the data for SDA, DPA, and CGA concentration were computed into the equation below, calculating the Predominant Trophic Mode Index (PTMI). The PTMI is calculated based on the ratio between the temporal variations in the content of fatty acids related to both autotrophic (SDA and DPA) and heterotrophic (CGA) feeding [10]:

$$
\operatorname{PTMI}=\left[\left(\frac{\operatorname{autFATM}\left(\mathrm{t}_{2}\right)}{\operatorname{autFATM}\left(\mathrm{t}_{1}\right)}\right)-1\right]-\left[\left(\frac{\operatorname{hetFATM}\left(\mathrm{t}_{2}\right)}{\operatorname{hetFATM}\left(\mathrm{t}_{1}\right)}\right)-1\right]
$$

where autFATM $=\mu \mathrm{g}$ of (SDA + DPA $) \mathrm{g}^{-1}$ of coral soft tissue, hetFATM $=\mu \mathrm{g}$ of CGA g ${ }^{-1}$ of coral soft tissue, $\mathrm{t}_{1}=$ initial sampling period, $\mathrm{t}_{2}=$ next sampling period. The result is dimensionless and indicates the prevalence of autotrophy in the case of positive values and the prevalence of heterotrophy for negative values. 


\subsubsection{Peroxynitrite $\left(\mathrm{ONOO}^{-}\right)$Quantification}

The tissue of coral and hydrocoral samples was analyzed for $\mathrm{ONOO}^{-}$concentration using the Amplitude ${ }^{\mathrm{TM}}$ Fluorimetric Peroxynitrite Quantification Kit (AAT Bioquest ${ }^{\circledR}$, Sunnyvale, CA, USA). The reagent DAX-J2 ${ }^{\mathrm{TM}}$ PON Green 99, specifically reacts with $\mathrm{ONOO}^{-}$, with high selectivity over ROS and other RNS, to generate a green fluorescent product detected at $\mathrm{Ex} / \mathrm{Em}=490 / 530 \mathrm{~nm}$. Briefly, approximately $0.5 \mathrm{~cm}^{2}$ of each coral/hydrocoral sample was cut using a cutter (HD Stainless Steel Stony Coral Cutter, Ocean Wonders, USA) and homogenized in assay buffer solution (provided by the manufacturer) using a sonicator (Frequency $70 \mathrm{KHz}$, Sonaer Ultrasonics, Farmingdale, NY, USA). The remaining piece of skeleton was discarded and homogenates were centrifuged at 10,000 $\mathrm{g}$ $\left(20 \mathrm{~min}, 4^{\circ} \mathrm{C}\right.$ ). The intermediary phase was used to perform the assay, according to the manufacturer instructions. Coral tissue can present green autofluorescence that can increase under temperature stress depending on symbionts clade [33]. To ensure no interferences with our measurement, we performed autofluorescence measurements on thermal stressed and non-stressed corals using the same tissue homogenate dilution used to perform the present assay (see Supplementary Materials). Measurements were performed on a solid black 96-well plate using a multi-mode microplate reader (FilterMax F5, Molecular Devices). Results were normalized to the protein content of the sample, which was determined using a commercial reagent kit based on the Bradford assay (Sigma-Aldrich, ST. Louis, MO, USA). Results were expressed as peroxynitrite concentration $(\mu \mathrm{M}) / \mathrm{mg}$ protein.

\subsection{Data Presentation and Statistical Analyses}

One-way ANOVAs were used to test: (i) if Mu. harttii and Mi. alcicornis shifted between feeding modes over time (PTMI data); (ii) if peroxynitrite levels significantly varied over time. If indicated, ANOVA was followed by the Student-Newman-Keuls multiple means procedure to detect statistically different $(p \leq 0.05)$ means. Data were checked for normality using Shapiro-Wilk's test and for homoscedasticity using Levene's test. Data were log transformed when necessary. To investigate a correlation between peroxynitrite and bleaching, and between the PTMI and sea surface temperature anomaly, a cross-correlation analysis for time series was performed. It was taken into account that data from time series tend to be autocorrelated, and that the degrees of freedom are overestimated, increasing Type I errors and the probability of detecting spurious associations when assuming a specified $\alpha$ value $[34,35]$. Thus, we corrected the number of degrees of freedom based on the sum of cross-products of the autocorrelations of tested variables over the examined lags [35,36], instead of removing the autocorrelation from the data. In the 'Results' section, Padj refers to P-value calculated using the corrected degrees of freedom. We only show the statistics for the lagged relationship with the highest correlation coefficient (R). To check if peroxynitrite levels and bleaching intensity were correlated for both species, we performed Pearson's correlation, considering data acquired from the three reef sites and from the beginning of the monitoring period up to the onset of bleaching (higher than $40 \%$ ). Peroxynitrite data were standardized among sites, equaling the highest level detected to one. Also, considering the many abiotic and biotic traits collected in the present study, and that principal component analysis (PCA) is an adequate method to integrate and interpret multiple data [37], we performed a PCA aiming to identify and summarize the correlation patterns among the multiple traits (bleaching, feeding plasticity, maximum temperature, degree heating weeks, sea surface temperature anomaly, and peroxynitrite). Also, in order to confirm the temporal patterns observed, the bleaching onset and recovery observed throughout the monitoring period was used as a discrete factor ('before', 'during', and 'after' bleaching) after scaling and centralizing the log-data using the prcomp function in vegan [38] package in the $R$ environment ( $R$ Core Team 2013). The factoextra package [39] was used to visualize graphically the data through the function "fviz_pca_biplot". 


\section{Results}

\subsection{Thermal Stress and Bleaching Frequency}

Seawater temperature measured during the monitoring period for each of the sites is summarized in Table 1. Sea surface temperature anomaly (SSTA) was observed throughout the monitoring period for all sites (Figures 2 and 3). SSTA positive deviations ranged from 0.1 to $1.1^{\circ} \mathrm{C}$ at Taquaruçu, from 0.1 to $1.0{ }^{\circ} \mathrm{C}$ at Funil, and from 0.1 to $1.3^{\circ} \mathrm{C}$ at Mourão.

Table 1. Seawater surface temperature $\left({ }^{\circ} \mathrm{C}\right)$ during the 6 month (from January 2015 to June 2016) monitoring period in the three sites of the Recife de Fora Marine Protected Area (Southwestern Atlantic) during the El Niño Southern Oscillation.

\begin{tabular}{cccc}
\hline Reef Site & Taquaruçu & Funil & Mourão \\
\hline Minimum temperature & 20.5 & 22.9 & 22.8 \\
Maximum temperature & 27.5 & 31.1 & 34.2 \\
Median & 24.7 & 26.5 & 26.7 \\
Mean & 24.7 & 26.5 & 26.7 \\
Standard deviation & 1.0 & 1.0 & 0.9 \\
Standard error & 0.2 & 0.2 & 0.2 \\
\hline
\end{tabular}

Critical thermal stress for corals, indicated by degree heating weeks (DHW) values of $4.5^{\circ} \mathrm{C}$-weeks, was observed from April to May at Taquaruçu site (Figures 2 and 3). For this locality, Mi. alcicornis showed signs of bleaching during the entire monitoring period, except for the second half of January and first half of June, while 100\% bleaching was observed from mid-March to mid-May (Figure 2). Mussismilia harttii showed bleaching signs mainly from April to May, with highest bleaching frequency (67\%) from mid-April to May (Figure 2).

DHW values of $6{ }^{\circ} \mathrm{C}$-weeks or greater were observed from April to mid-June at Funil site (Figures 2 and 3). Bleaching was observed for Mi. alcicornis from March to May, with the highest bleaching frequency (86\%) observed in mid-April. In turn, $M u$. harttii showed bleaching signs between March (20\%) and mid-May (67\%) (Figure 3).

No critical thermal stress indicated as DHW was observed for the site Mourão (Figures 2 and 3), however, maximum temperatures (up to $34.2{ }^{\circ} \mathrm{C}$ ) were registered for this location. Bleaching for $\mathrm{Mi}$. alcicornis was observed from mid-February to May, with the highest bleaching frequency (60\%) in May. $\mathrm{Mu}$. harttii bleached from March to May, with the highest bleaching frequency (53\%) observed in the first half of May (Figure 3).

\subsection{Predominant Trophic Mode Index}

Significant shifts of PTMI were observed for $M u$. harttii at all sites (ANOVA, $1.19 \leq \mathrm{F} \leq 1.631,0.001$ $<p \leq 0.006$, Figure 3). At Taquaruçu site, a significant predominance of heterotrophy was observed during the second half of January and February, while autotrophy was predominant during the first half of February (SNK, $p<0.001$ ). At Funil, heterotrophy was significantly dominant during the entire month of March (SNK, $p<0.001$ ), while autotrophy prevailed the rest of the monitoring period. At Mourão site, autotrophy prevailed during the first half of February (SNK, $p=0.05)$. However, it was followed by a significant heterotrophy peak in the second half of February (SNK, $p=0.006)$. Cross-correlation analysis shows that SSTA was associated with PTMI for $M u$. harttii for all three sites $(-0.783 \leq \mathrm{R} \leq-0.638,0.004 \leq \mathrm{Padj} \leq 0.05,9.4 \leq \mathrm{df} \leq 10.8)$ with a lag of 15 days for Taquaruçu and Funil, and of 30 days for Mourão, which means that a peak in sea surface temperature anomaly preceded the heterotrophy peak by 15 or 30 days (Table 2, Figure 3). On the contrary to Mu. harttii, Mi. alcicornis displayed a near-equilibrium between feeding modes at all sites, with PTMI values not varying significantly (ANOVA, $3.62 \leq \mathrm{F} \leq 12.38,0.16 \leq p \leq 0.34$, Figure 2). Accordingly, no correlation between PTMI and SSTA $(P \geq 0.05)$ was observed for all collecting sites (Table 2$)$. 
Millepora alcicornis
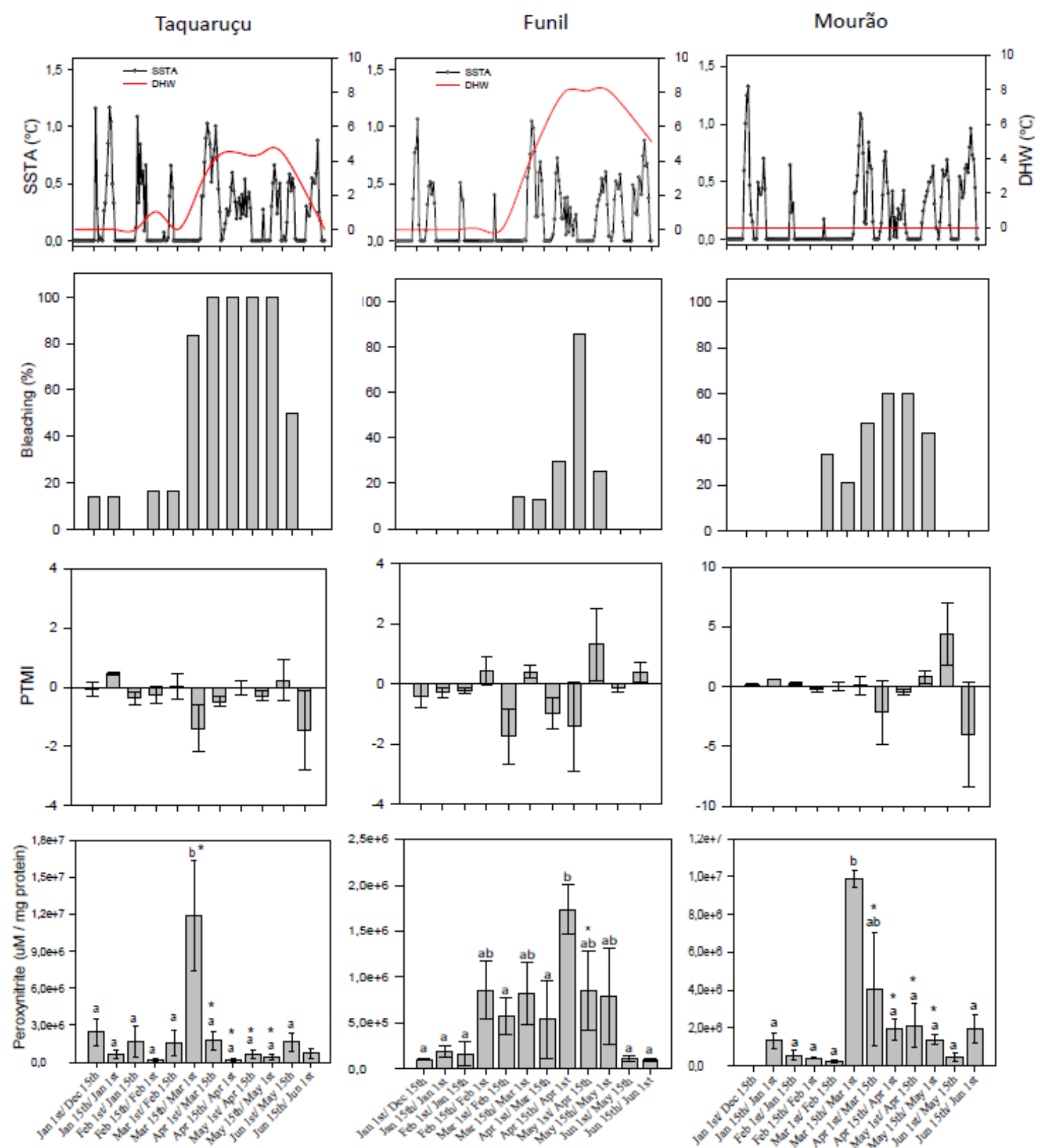

Figure 2. Thermal stress parameters [degree heating weeks (DHW) and daily sea surface temperature anomaly (SSTA)], bleaching frequency (\%), Predominant Trophic Mode Index (PTMI), and peroxynitrite levels ( $\mu \mathrm{M} / \mathrm{mg}$ protein) for Millepora alcicornis at the three sites (Taquaruçu, Funil, and Mourão) of the Recife de Fora Marine Protected Area (Southwestern Atlantic), from January 2015 to June 2016, during El Niño Southern Oscillation. For peroxynitrite, different letters indicate significant differences over time ( $p \leq 0.05)$, and asterisks $\left({ }^{*}\right)$ indicate more than $40 \%$ bleaching frequency observed. Data on PTMI and peroxynitrite are means \pm s.e.m of three to four samples. 
Mussismilia harttii
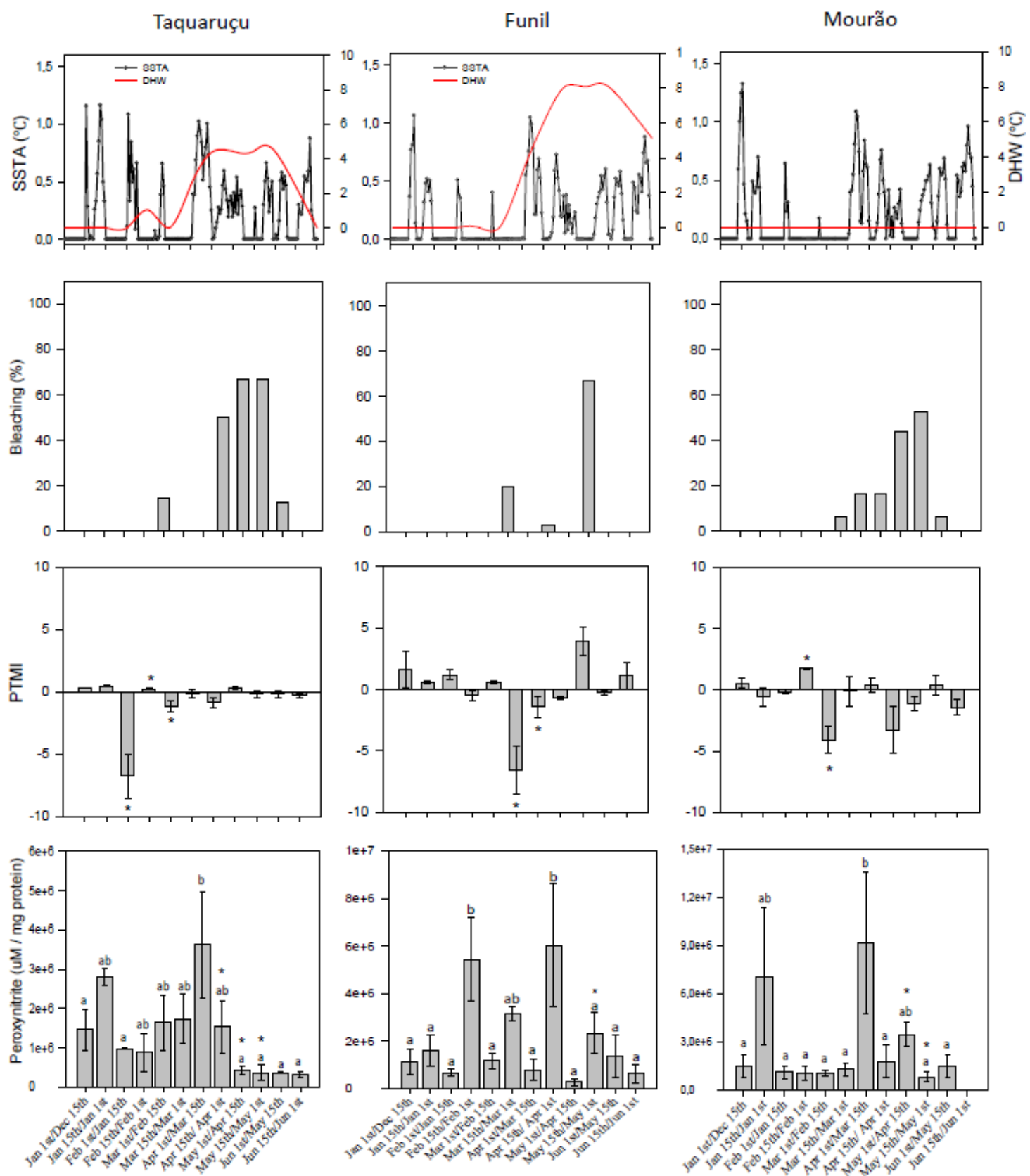

Figure 3. Thermal stress parameters [degree heating weeks (DHW) and daily sea surface temperature anomaly (SSTA)], bleaching frequency (\%), Predominant Trophic Mode Index (PTMI), and peroxynitrite levels ( $\mu \mathrm{M} / \mathrm{mg}$ protein) for Mussismilia harttii at the three sites (Taquaruçu, Funil, and Mourão) of the Recife de Fora Marine Protected Area (Southwestern Atlantic), from January 2015 to June 2016, during El Niño Southern Oscillation. For PTMI data, positive and negative values indicate prevalence of autotrophy and heterotrophy, respectively, with asterisks $\left(^{*}\right)$ indicating significant shifts of feeding mode prevalence over time $(p \leq 0.05)$. For peroxynitrite data, different letters indicate significant differences over time $(p \leq 0.05)$ and asterisks $\left(^{*}\right)$ indicate more than $40 \%$ bleaching frequency observed. Data on PTMI and peroxynitrite are means \pm s.e.m of three to four samples. 


\subsection{Peroxynitrite $\left(\mathrm{ONOO}^{-}\right)$Generation}

Significant differences in $\mathrm{ONOO}^{-}$levels over time were observed for Mi. alcicornis (ANOVA, 3.25 $\leq \mathrm{F} \leq 4.555,0.001<p \leq 0.007$, Figure 2) and Mu. harttii (ANOVA, $2.235 \leq \mathrm{F} \leq 5.121,0.001<p \leq 0.045$, Figure 3) at all sites. Mi. alcicornis showed a significant increase in $\mathrm{ONOO}^{-}$production in the first half of May at Taquaruçu (SNK, $p \leq 0.004$ ) and Mourão (SNK, $p \leq 0.003$ ), and in the first half of April at Funil (SNK, $p \leq 0.017$ ). Mu. harttii presented significantly higher levels of $\mathrm{ONOO}^{-}$in the second half of March at Taquaruçu (SNK, $p \leq 0.044$ ) and in first half of May for Mourão (SNK, $p \leq 0.043$ ). Two peaks of $\mathrm{ONOO}^{-}$production at Funil were observed in the first half of February and March (SNK, $p \leq 0.041$ ). In all cases, $\mathrm{ONOO}^{-}$generation significantly decreased after bleaching peaks (Figures 2 and 3 ).

A significant correlation was observed between $\mathrm{ONOO}^{-}$levels and bleaching intensity for $\mathrm{Mi}$. alcicornis $(p<0.001$, Pearson correlation coefficient $=0.81)$ and $M u$. harttii $(p=0.001$, Pearson correlation coefficient $=0.64)($ Figure 4$)$.

Mi. alcicornis

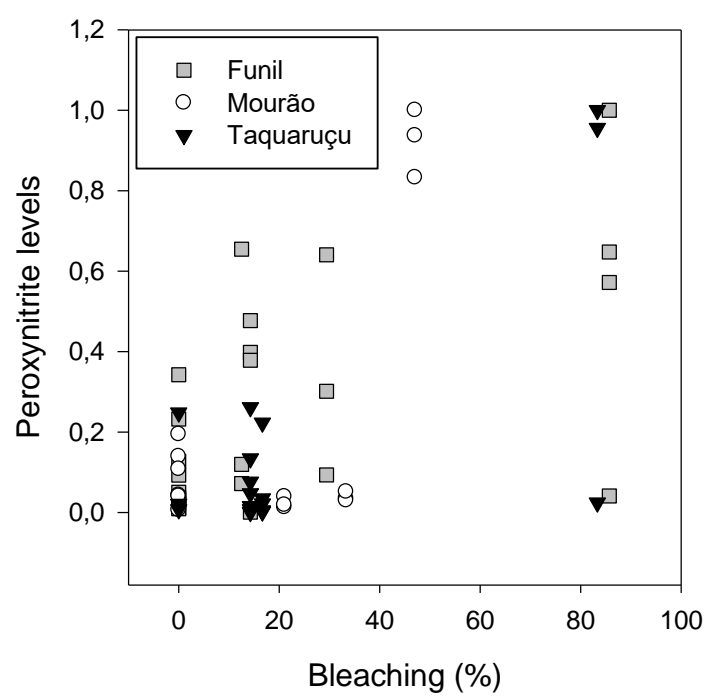

Mu. harttii

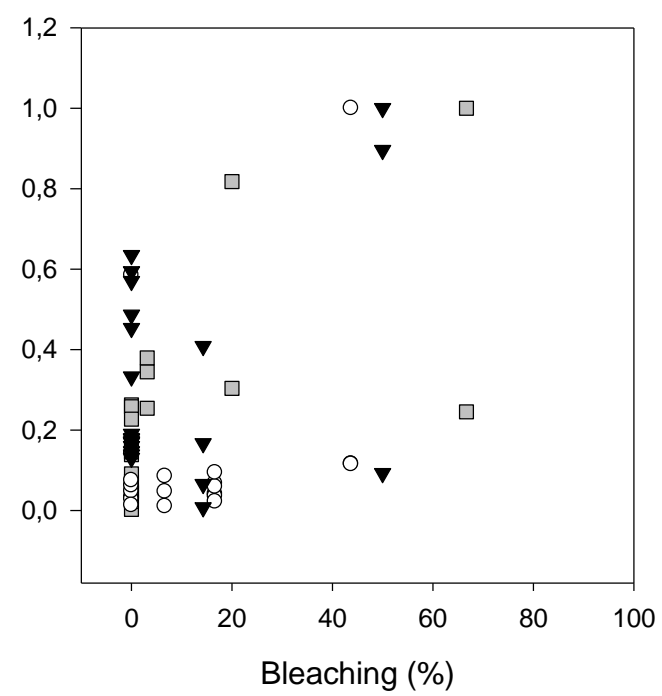

Figure 4. Correlation plot of peroxynitrite levels (standardized data) versus bleaching frequency for Millepora alcicornis and Mussismilia harttii, considering data from the three sites together. Highest peroxynitrite and bleaching levels were adjusted according the time lag observed for each of the sites, which varied from 0 to 30 days. A significant correlation was observed between $\mathrm{ONOO}^{-}$levels and bleaching intensity for Mi. alcicornis $(p<0.001$, Pearson correlation coefficient $=0.81)$ and $M u$. harttii $(p=0.001$, Pearson correlation coefficient $=0.64)$.

Cross-correlation analysis indicated species-specific time lags between peroxynitrite generation and bleaching for Taquaruçu and Funil. Bleaching and peroxynitrite were correlated with no lag $(\mathrm{R}$ $=0.808$, Padj $=0.003)$ and a 15 days lag $(R=0.63$, Padj $=0.04)$ for M. alcicornis from the locality of Funil $(\mathrm{df}=7.3)$ (Table 2). Peroxynitrite and bleaching were also correlated in $M$. harttii with a 15 days lag both at Funil ( $\mathrm{R}=0.66$, Padj $=0.03$, ) and Taquaruçu $(\mathrm{R}=0.75$, Padj $=0.01, \mathrm{df}=6.8$; Table 2$)$. No correlation between peroxynitrite generation and bleaching was observed in Mourão $(P>0.05)$, where no cumulative thermal stress (as DHW) was detected, and a lower bleaching frequency was observed for both species.

\subsection{Principal Component Analysis}

All traits were grouped together [bleaching, maximum temperature (MaxTemp), degree heating weeks (DHW), sea surface temperature anomaly (SSTA), peroxynitrite, auto- and heterotrophy] into a multivariate analysis (PCA) for Mi. alcicornis and Mu. harttii. The two main eigenvectors retained, respectively, $60.6 \%(\operatorname{Dim} 1=35.9 \%$; Dim2 $=24.7 \%)$ and 53.3\% (Dim1 $=36.4 \% ; \operatorname{Dim} 2=16.9 \%)$ of the total 
variance (Figure 5A,B). Bleaching, heterotrophy, and DHW were positively correlated with Dim1 (0.60 $<\mathrm{R}<0.90$ ) for both species. In turn, while SSTA was strongly correlated with DHW for Mi. alcicornis (Dim1, $0.41<\mathrm{R}<0.89$ ), it was more associated with MaxTemp for Mu. harttii (Dim1, $0.40<\mathrm{R}<0.51$ ). Peroxynitrite was associated with autotrophy for $M u$. harttii into $\operatorname{Dim} 1(-0.50<\mathrm{R}<-0.54)$, while it was correlated with heterotrophy for Mi. alcicornis into $\operatorname{Dim} 2(-0.57<\mathrm{R}<-0.59)$. When bleaching is used as a discrete factor ('before', 'during', and 'after'), autotrophy was grouped 'before' the bleaching event for $M u$. harttii, and 'before' and 'during' for Mi. alcicornis. Heterotrophy, however, was grouped during the bleaching event for both species. In turn, peroxynitrite was grouped 'before' the bleaching event for $M u$. harttii, and 'before' and 'during' for Mi. alcicornis, which goes in agreement with the different time lags observed for each species.

Table 2. Cross-correlation analysis testing i) the relationship between sea surface temperature anomaly and trophic mode, and ii) peroxynitrite and bleaching. P-values $\left(\mathrm{P}_{\text {adj }}\right)$ were calculated based on adjusted degrees of freedom $\left(\mathrm{df}_{\mathrm{adj}}\right)$ accounting for the autocorrelation of time series. Statistical descriptors are shown for the lagged relationship with the highest correlation coefficient (R). -, Correlation coefficient not significant at any lag. Bold numbers indicate significant $p$ values. ${ }^{*}$ indicate marginally significant $p$ values.

\begin{tabular}{|c|c|c|c|c|c|c|c|c|}
\hline \multirow[t]{3}{*}{ Site } & \multicolumn{8}{|c|}{ Sea surface temperature anomaly $x$ trophic mode } \\
\hline & \multicolumn{4}{|c|}{ Millepora alcicornis } & \multicolumn{4}{|c|}{ Mussimillia harttii } \\
\hline & $\begin{array}{l}\mathrm{Lag} \\
\text { (days) }\end{array}$ & $\mathrm{R}$ & $P_{a d j}$ & $\mathrm{df}_{\text {adj }}$ & $\begin{array}{c}\mathrm{Lag} \\
\text { (days) }\end{array}$ & $\mathrm{R}$ & $P_{\text {adj }}$ & $\mathrm{df}_{\mathrm{adj}}$ \\
\hline Taquaruçu & - & -0.218 & 0.53 & 10.2 & 15 & -0.692 & 0.03 & 9.5 \\
\hline Funil & - & -0.401 & 0.2 & 11.1 & 15 & -0.638 & 0.05 & 10.8 \\
\hline \multirow[t]{2}{*}{ Mourão } & - & -0.577 & 0.053 & 11.4 & 30 & -0.783 & 0.004 & 9.4 \\
\hline & \multicolumn{8}{|c|}{ Peroxynitrite $x$ bleaching } \\
\hline Taquaruçu & - & -0.27 & 0.4 & 8.6 & 15 & 0.75 & 0.01 & 6.8 \\
\hline Funil & $0 / 15$ & $0.63 / 0.81$ & $0.003 / 0.04$ & 7.3 & $15 / 30$ & $0.66 / 0.62$ & $0.03 / 0.06$ * & 7.6 \\
\hline Mourão & - & 0.36 & 0.39 & 8.2 & - & 0.09 & 0.79 & 8.5 \\
\hline
\end{tabular}

\section{A-Millepora alcicornis}

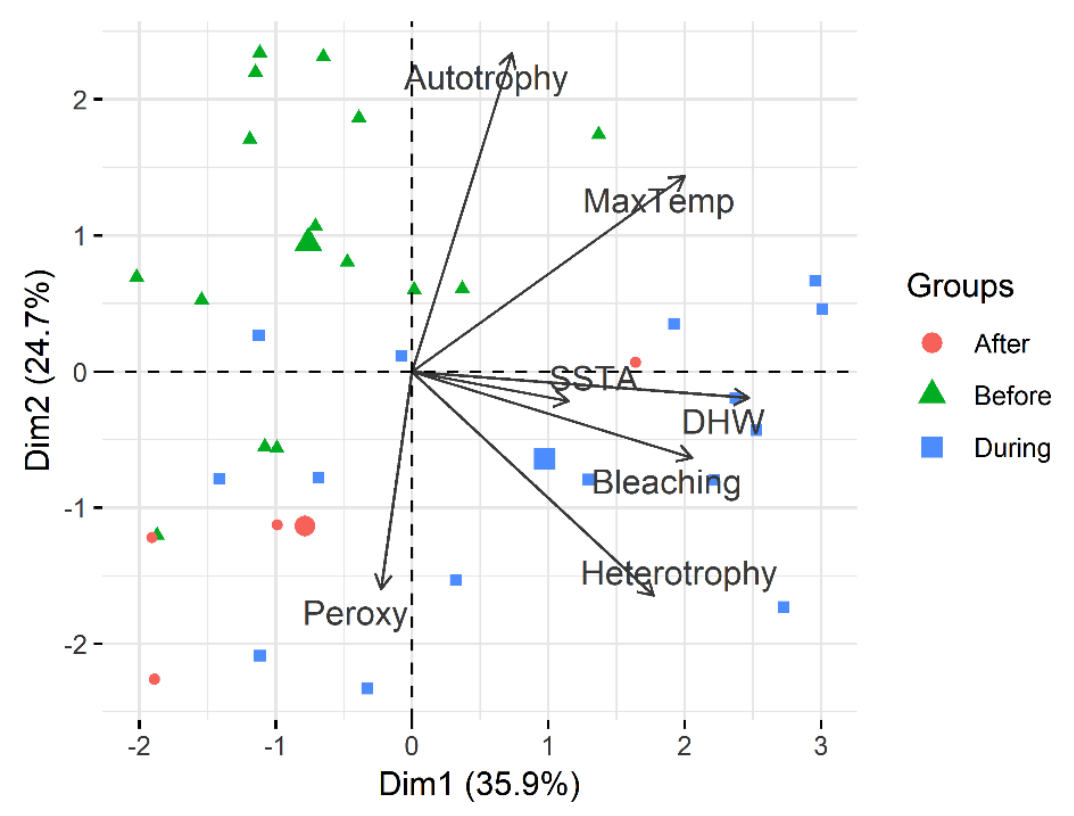

Figure 5. Cont. 


\section{B-Mussismilia harttii}

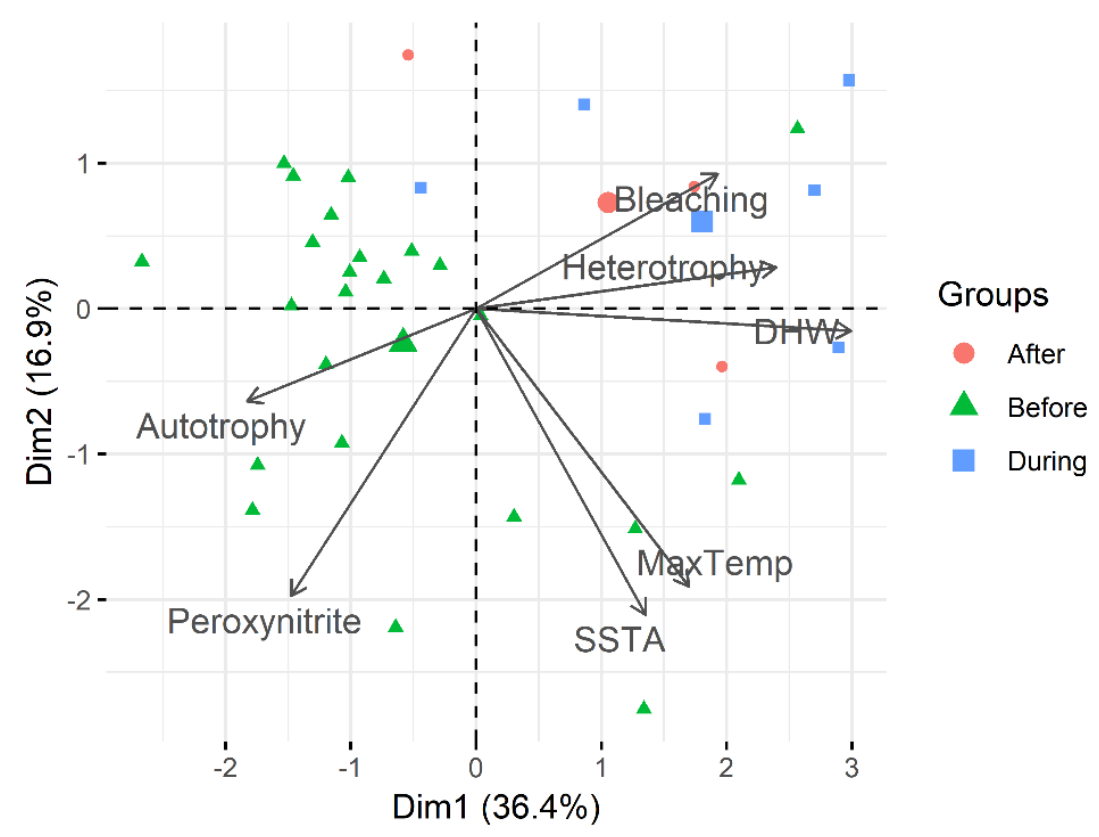

Figure 5. Principal component analysis of bleaching, degree heating weeks (DHW), sea surface temperature anomaly (SSTA), maximum temperature (MaxTemp), autotrophy, heterotrophy, and peroxynitrite in Millepora alcicornis (A) and Mussismilia harttii (B). All traits were grouped into 3 clusters: after, before, and during the bleaching event. The two main eigenvectors retained, respectively, $60.6 \%$ $(\operatorname{Dim} 1=35.9 \%$; $\operatorname{Dim} 2=24.7 \%)$ and $53.3 \%(\operatorname{Dim} 1=36.4 \%$; $\operatorname{Dim} 2=16.9 \%)$ of the total variance.

\section{Discussion}

This study brings new insights into the mechanisms involved in the breakdown of the cnidarian-dinoflagellate symbiosis during a natural bleaching event under El Niño influence. We showed that high peroxynitrite $\left(\mathrm{ONOO}^{-}\right)$levels are associated with bleaching occurrence and intensity, with however a species-specific time lag. Also, this study brings the first evidence of a thermally induced shift from auto- to heterotrophy in the scleractinian coral $M u$. hartii, while the hydrocoral Mi. alcicornis was unable to show such nutritional plasticity.

\subsection{Thermal Stress, Bleaching Frequency, and Feeding Mode Plasticity}

A positive correlation between large-scale bleaching ( $>50 \%-60 \%$ of the colonies investigated) and DHW was observed for both coral species in two out of the three monitored sites (Taquaruçu and Funil), in agreement with previous observations [2,29]. The third site (Mourão), which didn't experience DHW, presented a lower bleaching intensity ( $<60 \%$ of the colonies investigated), although still half of the coral colonies bleached during the highest thermal anomalies recorded. Such lack of correlation between bleaching and DHW was previously observed [40], and was related to the occurrence of small increases in temperature (lower than $1{ }^{\circ} \mathrm{C}$ above monthly mean) persisting over months. The comparison of the seawater temperature profiles of the three sites, however, suggests that bleaching at Mourão may be related to the highest sea surface temperature anomaly (SSTA) recorded among sites $\left(+1.3^{\circ} \mathrm{C}\right)$ and to other environmental stressors such as water quality. Mourão is indeed located in the most landward side of Recife de Fora conservation reef area, showing twofold higher average levels of nitrogen (up to $1.16 \mu \mathrm{mol} \mathrm{L}^{-1}$ ) than the seaward side-Taquaruçu [41]. Due to the fact that high levels of nitrogen in seawater have been linked to reduction in the bleaching threshold [33], high nitrogen concentration at Mourão could explain the bleaching occurrence, in the absence of DHW. 
Bleaching frequency was also species-specific, with Mi. alcicornis displaying twice higher bleaching frequency (up to $100 \%$ ) at all sites compared to $M u$. harttii. In agreement with our observation, hydrocorals were among the first reef-building species to undergo bleaching during the El Niño event (1982-1983) of the Pacific coast of Panama [42]. In addition, a recent study on South Atlantic Ocean reefs reported Millepora spp. as the most affected species during the bleaching events of 2016 and 2017 [43]. The higher sensitivity of hydrocorals to thermal stress compared to some scleractinian coral species, as observed here and in the aforementioned studies, may be related to their lower heterotrophic capacity. While the scleractinian coral $M u$. harttii significantly shifted between feeding modes, Mi. alcicornis trophic mode remained unaffected during the entire monitoring period. Previous studies have reported that corals rely on heterotrophy as a compensation mechanism for the reduced autotrophy resulting from bleaching [8-10,44]. As the size of corallites has already been described as a proxy for heterotrophic capacity [45], the high degree of heterotrophy in $M u$. harttii may be explained by its large corallite, with a diameter of $15 \mathrm{~mm}$ or larger [46], coupled with large tentacles, which also favor predation [47]. This is 50-fold greater than the gastropore diameter found in Mi. alcicornis $(0.3 \mathrm{~mm})$ [48]. Therefore, $M u$. harttii may have more resources than $M i$. alcicornis for enduring thermal stress events. The shifts to heterotrophy in $M u$. harttii were indeed correlated with the occurrence of sea surface temperature anomalies (SSTA). These findings are in concert with previous reports for other scleractinian coral species $[10,49,50]$ and can be associated with variability in oceanographical and meteorological phenomena [10,51,52].

\subsection{Peroxynitrite Generation and Bleaching}

It has been hypothesized that the deleterious effects of high levels of nitric oxide (NO) during bleaching are related to its conversion to $\mathrm{ONOO}^{-}$, which acts as a cytotoxic compound. Specifically, $\mathrm{ONOO}^{-}$, through mitochondrial membrane damage, may be responsible for the release of potent proapoptotic molecules that initiate an apoptotic cascade involved in the bleaching process $[14,15]$ In vivo production of $\mathrm{ONOO}^{-}$in the symbiotic sea anemone Exaiptasia pulchella indeed occurred under thermal stress; nonetheless, owing to the nonsignificant effect of $\mathrm{ONOO}^{-}$scavenger, its generation was considered insufficient to influence symbiont loss [16]. In contrast, our results bring the first evidence that $\mathrm{ONOO}^{-}$is an important mediator of bleaching in scleractinian corals and hydrocorals experiencing heat stress under field conditions. High levels of $\mathrm{ONOO}^{-}$were indeed detected shortly before the maximum bleaching frequency for both species at all sites (Figures 2 and 3) and a significant correlation was observed between the highest levels of $\mathrm{ONOO}^{-}$and the highest bleaching frequency (Figure 4). Additionally, species-specific time lag responses were detected through cross-correlation analysis regarding maximum $\mathrm{ONOO}^{-}$generation and maximum bleaching frequency, from 0 to 30 days prior bleaching. The different time lags found for each species, greater for $M u$. harttii (up to 30 days before) and shorter for Mi. alcicornis (up to 15 days before), were also reinforced by PCA that correlated $\mathrm{ONOO}^{-}$before bleaching occurrence for $\mathrm{Mu}$. harttii and during bleaching occurrence for Mi. alcicornis.

The species-specific time lag response for $\mathrm{ONOO}^{-}$generation and bleaching occurrence in the present study suggests a differential susceptibility to $\mathrm{ONOO}^{-}$and/or capacity to neutralize and counteract the deleterious effects of this highly reactive RNS. For example, the antioxidant capacity has been demonstrated as a critical component of stress tolerance in scleractinian corals [53] and antioxidant capacity has been reported to be approximately threefold lower in Mi. alcicornis than in $M u$. harttii [54]. Therefore, the lower antioxidant capacity observed in Mi. alcicornis can explain why this species present a smaller interval between $\mathrm{ONOO}^{-}$generation and bleaching, while $\mathrm{Mu}$. harttii, with a higher antioxidant capacity, presents a repeated and longer interval between $\mathrm{ONOO}^{-}$and bleaching. In addition, these species-specific time lags and antioxidant capacities are aligned with the different bleaching frequencies observed (higher and lower for Mi. alcicornis and Mu. harttii, respectively).

Also, it is worth noting that most studies on the role of RNS in the bleaching mechanisms were performed with laboratory experiments, which could differ from the present study with corals undergoing bleaching in the field [16]. Finally, despite the fact that the present study cannot prove that 
alternative bleaching pathways directly involving $\mathrm{ROS}$ or $\mathrm{NO}$ are as critical as $\mathrm{ONOO}^{-}$, we propose that this highly cytotoxic molecule may exert a more relevant influence in cnidarians' thermal bleaching process than previously suggested.

\section{Conclusions}

Our findings show that $\mathrm{ONOO}^{-}$may be an important mediator of bleaching in scleractinian corals and hydrocorals experiencing heat stress under field conditions, with consistent observation of higher levels preceding maximum bleaching occurrence in a species-specific time lag. Measuring $\mathrm{ONOO}^{-}$ may be an additional tool to quantitatively assess the stress level in corals, similar to chlorophyll and ROS. Further investigations are, however, needed to bring detailed insights into the mechanisms of $\mathrm{ONOO}^{-}$involved in the onset of bleaching. In addition, we show that SSTA may increase heterotrophic feeding and that the higher sensitivity of hydrocorals to thermal stress may be related to their lower heterotrophic input. The overall results may further the understanding of the biochemical mechanisms associated with bleaching, as well as of the trophic behavioral response that cnidarians may display when under thermal stress.

Supplementary Materials: The following are available online at http://www.mdpi.com/2076-2607/7/10/426/s1, Table S1: Autofluorescence data detected at Ex/Em $=490 / 530 \mathrm{~nm}$ (fluorescence/mg protein, mean $\pm \mathrm{SEM}, \mathrm{N}=6$ ) of two coral species, the scleractinian Mussismilia harttii and the hydrocoral Millepora alcicornis, before (samples collected from December to March) and during thermal stress (April to June), and their statistical descriptors. No significant differences in fluorescence between thermal stressed and non-stressed corals, for each species, were indicated by Student's t-test.

Author Contributions: L.F.B.M. and A.B. participated on the field work design. A.B., M.M., A.Z.G., A.I. and S.M. contributed with infrastructure/material/technical support. L.F.B.M., C.D., M.M., A.Z.G., T.N.S.B. and A.I. analyzed the data. L.F.B.M. and S.C.F. performed statistical analysis. L.F.B.M., S.C.F., M.M. and C.F.P. wrote the original draft. All authors read and revised the manuscript.

Funding: This research was funded by the International Development Research Centre (IDRC, Ottawa, Canada), Coordenação de aperfeiçoamento de Pessoal de Nível Superior (CAPES—Programa Ciências do Mar, Brasília, DF, Brazil), and Conselho Nacional de Desenvolvimento Científico e Tecnológico (CNPq-Instituto Nacional de Ciência e Tecnologia de Toxicologia Aquática, Brasília, DF, Brazil). The APC was funded by Centre Scientifique de Monaco (CSM). AB is a research fellow from the Brazilian CNPq (Proc. \# 304430 2009-9); SCF is a post-doc fellow from FAPESP (\#2017/05310-9 and \#2018/17252-6), and LFBM was a graduate fellow from CAPES.

Acknowledgments: We would like to thank Prof. Sayuri Miyamoto for providing infrastructure, Dr. Adriano Chaves-Filho for his kind assistance, and MSc. Joseane A. Marques and Dr. Rafael Duarte for helping with R scripts. Dr. Emiliano Calderon, MSc. Cristiano Pereira, Dr. Douglas Abrantes, and Coral Vivo's staff are acknowledged for their support in field work. The Coral Vivo Project and its sponsors Petrobras, through the Petrobras Environmental Program, and Arraial d'Ajuda Eco Parque are acknowledged for their support in field research.

Conflicts of Interest: On behalf of all authors, the corresponding author states that there is no conflict of interest.

\section{References}

1. Hughes, T.P.; Anderson, K.D.; Connolly, S.R.; Heron, S.F.; Kerry, J.T.; Lough, J.M.; Baird, A.H.; Baum, J.K.; Berumen, M.L.; Bridge, T.C.; et al. Spatial and temporal patterns of mass bleaching of corals in the Anthropocene. Science. 2018, 359, 80-83. [CrossRef] [PubMed]

2. Claar, D.C.; Szostek, L.; McDevitt-Irwin, J.M.; Schanze, J.J.; Baum, J.K. Global patterns and impacts of El Niño events on coral reefs: A meta-analysis. PLoS ONE 2018, 13, e0190957. [CrossRef]

3. Lough, J.M.; Anderson, K.D.; Ughes, T.P. Increasing thermal stress for tropical coral reefs: 1871-2017. Sci. Rep. 2018, 8, 6079. [CrossRef] [PubMed]

4. Downs, C.A.; Mueller, E.; Phillips, S.; Fauth, J.E.; Woodley, C.M. A molecular biomarker system for assessing the health of coral (Montastrea faveolata) during heat stress. Mar. Biotechnol. 2000, 2, 533-544. [CrossRef]

5. LaJeunesse, T.C.; Parkinson, J.E.; Gabrielson, P.W.; Jeong, H.J.; Reimer, J.D.; Voolstra, C.R.; Santos, S.R. Systematic revision of Symbiodiniaceae highlights the antiquity and diversity of coral endosymbionts. Curr. Biol. 2018, 28, 2570-2580. [CrossRef] [PubMed] 
6. Muscatine, L.; Porter, J.W. Reef corals: mutualistic symbioses adapted to nutrient-poor environments. Bio. Sci. 1997, 27, 454-460. [CrossRef]

7. Muscatine, L. The role of symbiotic algae in carbon and energy flux in coral reefs. In Ecosystems of the World; Dubinsky, Z., Ed.; Elsevier: Amsterdam, The Netherlands, 1990; pp. 75-87.

8. Grottoli, A.G.; Rodrigues, L.J.; Palardy, J.E. Heterotrophic plasticity and resilience in bleached corals. Nature 2006, 440, 1186-1189. [CrossRef] [PubMed]

9. Hughes, A.D.; Grottoli, A.G. Heterotrophic compensation: a possible mechanism for resilience of coral reefs to global warming or a sign of prolonged stress? PLoS ONE 2012, 8, e81172. [CrossRef]

10. Mies, M.; Guth, A.Z.; Tenório, A.A.; Banha, T.N.S.; Waters, L.G.; Polito, P.S.; Taniguchi, S.; Bícego, M.C.; Sumida, P.Y.G. In situ shifts of predominance between autotrophic and heterotrophic feeding in the reef-building coral Mussismilia hispida: an approach using fatty acid trophic markers. Coral Reefs 2018, 37, 677-689. [CrossRef]

11. Lesser, M.P. Elevated temperatures and ultraviolet radiation cause oxidative stress and inhibit photosynthesis in symbiotic dinoflagellates. Limnol. Oceanogr. 1996, 41, 271-283. [CrossRef]

12. Lesser, M.P. Oxidative stress causes coral bleaching during exposure to elevated temperatures. Coral Reefs 1997, 16, 187-192. [CrossRef]

13. Downs, C.A.; Fauth, J.E.; Halas, J.C.; Dustan, P.; Bemiss, J.; Woodley, C.M. Oxidative stress and seasonal coral bleaching. Free Rad Biol. Med. 2002, 33, 533-543. [CrossRef]

14. Pyper, B.J.; Peterman, R.M. Comparison of methods to account for autocorrelation in correlation analyses of fish data. Can. J. Fish Aquat. Sci. 1998, 55, 2127-2140. [CrossRef]

15. Wiedenmann, J.; D’Angelo, C.; Smith, E.G.; Hunt, A.N.; Legiret, F.E.; Postle, A.D.; Achterberg, E.P. Nutrient enrichment can increase the susceptibility of reef corals to bleaching. Nat. Clim. Change 2013, 3, 160-164. [CrossRef]

16. Hawkins, T.D.; Davy, S.K. Nitric oxide and coral bleaching: is peroxynitrite generation required for symbiosis collapse. J. Exp. Biol. 2013, 216, 3185-3188. [CrossRef] [PubMed]

17. Hawkins, T.D.; Bradley, B.J.; Davy, S.K. Nitric oxide mediates coral bleaching through an apoptotic-like cell death pathway: evidence from a model sea anemone-dinoflagellate symbiosis. FASEB J. 2013, 27, 4790-4798. [CrossRef]

18. Sebens, K.P.; Koehl, M.A.R. Predation on zooplankton by the benthic anthozoans Alcyonium siderium (Alcyonacea) and Metricium senile (Actiniaria) in the New England subtidal. Mar. Biol. 1984, 81, 255-271. [CrossRef]

19. Nielsen, D.A.; Petrou, K.; Gates, R.D. Coral bleaching from a single cell perspective. ISME J. 2018, 12, 1558-15675. [CrossRef] [PubMed]

20. Lesser, M.P. Oxidative stress in marine environments: biochemistry and physiological Ecology. Annu. Rev. Physiol. 2006, 68, 253-278. [CrossRef]

21. Teixeira, C.D.; Leitão, R.L.L.; Ribeiro, F.V.; Moraes, F.C.; Neves, L.M.; Bastos, A.C.; Pereira-Filho, G.H.; Kampel, M.; Salomon, P.S.; Sá, J.A.; et al. Sustained mass coral bleaching (2016-2017) in Brazilian turbid-zone reefs: taxonomic, cross-shelf and habitat-related trends. Coral Reefs 2019, 38, 801-813. [CrossRef]

22. Tremblay, P.; Gori, A.; Maguer, J.F.; Hoogenboom, M.; Ferrier-Pagès, C. Heterotrophy promotes the re-establishment of photosynthate translocation in a symbiotic coral after heat stress. Sci. Rep. 2016, 6, 38112. [CrossRef] [PubMed]

23. Hawkins, T.D.; Davy, S.K. Nitric oxide production and tolerance differ among Symbiodinium types exposed to heat stress. Plant Cell Physiol. 2012, 53, 1889-1898. [CrossRef] [PubMed]

24. Szabó, C.; Ischiropoulos, H.; Radi, R. Peroxynitrite: biochemistry, pathophysiology and development of therapeutics. Nature 2007, 6, 662-680. [CrossRef] [PubMed]

25. Maynard, J.A.; Turner, P.T.; Anthony, K.R.N.; Baird, A.H.; Berkelmans, R.; Eakin, C.M.; Johnson, J.; Marshall, P.A.; Packer, G.R.; Rea, A.; et al. TeefTemp: An interactive monitoring system for coral bleaching using high-resolution SST and improves stress predictors. Geo. Res. Lett. 2008, 35, L05603. [CrossRef]

26. Liu, G.; Skirving, W.J.; Strong, A.E. Remote sensing of sea surface temperatures during 2002 barrier reef coral bleaching. Eos, Trans. Am. Geophys. Union 2003, 84, 137-144. [CrossRef]

27. Liu, G.; Strong, A.E.; Skirving, W.J.; Arzayus, L.F. Overview of NOAA Coral Reef Watch Program's Near-real-time Satellite Global Bleaching Monitoring Activities. In Proceedings of the 10th international coral reef symposium, Okinawa, Japan, 28 June-2 July 2004; NOAA: Washington, DC, USA, 2006; pp. 1783-1793. 
28. Liu, G.; Rauenzahn, J.L.; Heron, S.F.; Eakin, C.M.; Skirving, W.J.; Christensen, T.R.L.; Strong, A.E. NOAA coral reef watch $50 \mathrm{~km}$ satellite sea surface temperature-based decision support system for coral bleaching management. In NOAA technical Report NESDIS 143; NOAA: Washington, DC, USA, 2013; p. 33.

29. Kayanne, H. Validation of degree heating weeks as a coral bleaching index in the northwestern Pacific. Coral Reefs 2017, 36, 63-70. [CrossRef]

30. Smith, T.B.; Nemeth, R.S.; Blondeau, J.; Clanan, J.M.; Kadison, E.; Herzlied, S. Assessing coral reef heath across onshore to offshore stress gradients in the US Virgin Islands. Mar. Poll. Bull. 2008, 56, 1983-1991. [CrossRef]

31. Mies, M.; Chaves-Filho, A.B.; Miyamoto, S.; Guth, A.Z.; Tenório, A.A.; Castro, C.B.; Pires, D.O.; Calderon, E.N.; Sumida, P.Y.G. Production of three symbiosis-related fatty acids by Symbiodinium types in clades A-F associated with marine invertebrate larvae. Coral Reefs 2017, 36, 1319-1328. [CrossRef]

32. Conlan, J.A.; Rocker, M.M.; Francis, D.S. A comparison of two common sample preparation techniques for lipid and fatty acid analysis in three different coral morphotypes reveals quantitative and qualitative differences. Peer J. 2017, 5, e3645. [CrossRef]

33. Yuama, I.; Harii, S.; Hidaka, M. Algal symbiont type affects gene expression in juveniles of the coral Acropora tenuis exposed thermal stress. Mar. Envir. Res. 2012, 76, 41-47. [CrossRef]

34. Fuller, W.A. Introduction to statistical time series; John Wiley \& Sons: Hoboken, NJ, USA, 2009.

35. Roder, C.; Fillinger, L.; Jantzen, C.; Schmidt, G.M.; Khokiattiwong, S.; Richter, C. Trophic response of corals to large amplitude internal waves. Mar. Ecol. Prog. Ser. 2010, 412, 113-128. [CrossRef]

36. Chelton, D.B. Commentary: Short-term climatic variability in the Northeast Pacific Ocean. In The influence of ocean conditions on the production of salmonids in the North Pacific; Pearcy, W., Ed.; Oregon State University Press: Corvallis, OR, USA, 1984; pp. 87-99.

37. Allen, J.I.; Moore, M.N. Environmental prognostics: is the current use of biomarkers appropriate for environmental risk evaluation. Mar. Environ. Res. 2004, 58, 227-232. [CrossRef] [PubMed]

38. Oksanen, J.; Blanchet, F.G.; Kindt, R.; Legendre, P.; Minchin, P.R.; O’hara, R.B.; Wagner, H. R Package 'vegan'. Community ecology package, version, 2(9). 2013.

39. Kassambara, A.; Mundt, F. Factoextra. Extract and Visualize the Results of Multivariate Data Analyses. $R$ package version 2016.

40. Le Hohaic, M.; Ross, C.L.; Cornwall, C.E.; Comeau SLowe, R.; McCulloch, M.T.; Schoepf, V. Marine heatwave causes unprecedented regional mass bleaching of thermally resistant corals in northwestern Australia. Sci. Rep. 2017, 7, 14999. [CrossRef] [PubMed]

41. Costa, O.S.; Attrill, M.J.; Nimmo, M. Seasonal and spatial controls on the delivery of excess nutrients to nearshore and offshore coral reefs of Brazil. J. Mar. Sys. 2006, 60, 63-74. [CrossRef]

42. Glynn, P.W.; Weerdt, W.H. Elimination of two reef-building hydrocorals following the 1982-83 El Niño warming event. Science 1991, 253, 69-71. [CrossRef] [PubMed]

43. Trapido-Rosenthal, H.G.; Sharp, K.H.; Galloway, T.S.; Morrall, C.E. Nitric oxide and cnidarian-dinoflagellate symbioses: pieces of a puzzle. Amer. Zool. 2001, 41, 247-257. [CrossRef]

44. Weis, V.M. Cellular mechanisms of Cnidarian bleaching: stress causes the collapse of symbiosis. J. Exp. Biol. 2008, 211, 59-66. [CrossRef]

45. Anthony, K.R.N.; Fabricius, K.E. Shifting roles of heterotrophy and autotrophy in coral energetics under varying turbidity. J. Exp. Mar. Biol. Ecol. 2000, 252, 221-253. [CrossRef]

46. Nunes, F.; Fukami, H.; Vollmer, S.V.; Norris, R.D.; Knowlton, N. Re-evaluation of the systematics of the endemic corals of Brazil by molecular data. Coral Reefs 2008, 27, 423-432. [CrossRef]

47. Siebeck, U.E.; Marshall, N.J.; Kluter, A.; Hoegh-Guldberg, O. Monitoring coral bleaching using a colour reference card. Coral Reefs 2006, 25, 453-460. [CrossRef]

48. Amaral, F.M.D.; Steiner, A.Q.; Broadhurst, M.K.; Cairns, S.D. An overview of the shallow-water calcified hydroid from Brazil (Hydrozoa: Cnidaria), including the description of a new species. Zootaxa 2008, 1930, 56-68. [CrossRef]

49. Hoogenboom, M.; Rodolfo-Metalpa, R.; Ferrier-Pagès, C. Co-variation between autotrophy and heterotrophy in the Mediterranean coral Cladocora caespitosa. J. Exp. Biol. 2010, 213, 2399-2409. [CrossRef] [PubMed]

50. Ferrier-Page's, C.; Peirano, A.; Abbate, M.; Cocito, S.; Negri, A.; Rottier, C.; Riera, P.; Rodolfo-Metalpa, R.; Reynaud, S. Summer autotrophy and winter heterotrophy in the temperate symbiotic coral Cladocora caespitosa. Limnol. Oceanogr. 2011, 56, 1429-1438. [CrossRef] 
51. Perez SWeis, V. Nitric oxide and cnidarians bleaching: an eviction notice mediates breakdown of a symbiosis. J. Exp. Biol. 2006, 209, 2804-2810. [CrossRef] [PubMed]

52. Ross, C. Nitric oxide and heat shock protein 90 co-regulate temperature-induced bleaching in the soft coral Eunicea fusca. Coral Reefs 2014, 33, 513-522. [CrossRef]

53. Jin, Y.K.; Lundgren, P.; Lutz, A.; Raina, J.-B.; Howells, E.J.; Paley, A.S.; Willis, B.L.; van Oppen, M.J.H. Genetic markers for antioxidant capacity in a ree-building coral. Sci. Adv. 2016, 2, e1500842. [CrossRef]

54. Marangoni, L.F.B.; Dalmolin, C.; Marques, J.A.; Klein, R.D.; Abrantes, D.; Pereira, C.M.; Calderon, E.N.; Castro, C.B.; Bianchini, A. Oxidative stress biomarkers as potential tools in reef degradation monitoring: a study case in a South Atlantic reef under influence of the 2015-2016 El Niño/Southern Oscillation (ENSO). Ecol. Ind. 2019, 106, 105533. [CrossRef]

(C) 2019 by the authors. Licensee MDPI, Basel, Switzerland. This article is an open access article distributed under the terms and conditions of the Creative Commons Attribution (CC BY) license (http://creativecommons.org/licenses/by/4.0/). 